\title{
Research on the Trend and Characteristics of Talent Localization in Multinational Corporations
}

\author{
Yamei Zhang \\ Yunnan university of finance and economics \\ International business school \\ Kunming, China \\ 624209199@qq.com
}

\author{
Ying Yang* \\ Yunnan university of finance and economics \\ International business school \\ Kunming, China \\ 11476423@qq.com
}

\begin{abstract}
With the help of globalization and the "Belt and Road Initiative," Chinese companies have accelerated the pace of "going out". There is a good opportunity for the development of multinational companies in China. In order to make transnational corporations more adaptable to the host country environment and improve management efficiency in all aspects, the trend of localization of multinational corporations has become increasingly evident. At different levels, talent localization also shows different characteristics. On the basis of expounding the global trend of localization of talents in transnational corporations, this paper analyzes the different characteristics of localization in different positions and different levels of development of the host country, so that multinational corporations can establish a reasonable structure of human resources.
\end{abstract}

Keywords-"One Belt And One Road"; multinational Corporation; talent Localization; feature

\section{INTRODUCTION}

"One Belt and One Road" is the abbreviation of the two cooperative development strategies of the "Silk Road Economic Belt" and "21st Century Maritime Silk Road". Historically, the land-based Silk Road and the Maritime Silk Road are the major channels for China's economic, trade, and cultural exchanges with Central Asia, Southeast Asia, South Asia, West Asia, East Africa, and Europe. It will fully rely on the existing bilateral and multilateral mechanisms of China and relevant countries and rely on existing and effective regional cooperation platforms. The "One Belt and One Road" strategy lies in the formation of a community of interests, a community of fate, and a community of responsibility that are political mutual trust, economic integration, and cultural inclusion.

Southeast Asia is the center of gravity of the "Belt and Road Initiative" and has very close geographic relationships with China. South Asia is one of the key areas for the promotion of the "Belt and Road" initiative. The participation of South Asian countries is of great significance to the "Belt and Road" initiative. And South Asia has taken the lead in cooperation with China and countries along the Belt and Road initiative.

The "One Belt and One Road" initiative has provided excellent opportunities for the development of multinational companies in China. Driven by the "One Belt and One Road" initiative, we have accelerated the pace of "going global" and enhanced our ability to operate internationally. China's multinational companies have grown from small to large, from small to large, and from weak to strong, and have gradually grown into global transnational corporations. An important member of the family. While having good prospects and great opportunities, in the face of differences in the level of economic development, political and legal systems, and social and cultural conventions among countries and regions, how to adapt to the overseas subsidiaries and their branches of multinational corporations in China? And integrating a completely new environment with the domestic market is also a new challenge. In terms of staffing, the expansion of overseas operations of multinational companies mainly depends on the distribution of foreign personnel [1]. They occupy important management positions in foreign subsidiaries of multinational companies.

Managers selected from the home country are more familiar with the parent company's goals, systems, and practices, and are loyal to the parent company. However, the cost of sending staff abroad is high, and it is difficult for managers to work effectively in a heterogeneous culture due to cultural differences. Therefore, multinational companies will take into account various factors when selecting either foreign or local host countries to select the most suitable talent. With the maturity of global operations of transnational corporations and the changes in the external environment, the trend of localization of multinational corporations has become increasingly evident. In the key positions, more and more attention has been paid to training and developing local management personnel and gradually replacing their foreign counterparts.

Under the "One Belt and One Road" approach, the trend of talent localization in multinational companies has become increasingly clear in recent years. However, the localization of talents at different levels is not the same. Chinese multinational corporations also show different characteristics in localization of talents in different host countries.

This article will explore the research questions based on the following structure. In the second part we described the literature background of the study. Specifically, it summarizes

*Corresponding author 
the achievements made by the previous generations in the localization of multinational corporations and puts forward the insufficiency in localization characteristics. The discussion assumes several aspects that affect the degree of localization of multinational corporations. In the third part, we used the previous data, compared the results and analyzed the data to support our hypothesis. In the fourth part, the influence factors that lead to the different degree of localization of multinational companies are introduced. The fifth part is to combine the main findings of the study together to make a summary statement.

\section{LITERATURE REVIEW}

The "One Belt and One Road" strategy has provided multinational companies with their own advantages. Therefore, more and more domestic companies take this opportunity to implement the "go global" strategy. "Globalization thinking, localization action" is the guideline of action for multinational corporations in the global market competition and the unremitting efforts to achieve the battle goal. In many localization strategies, talent localization is the most important.

People-oriented management, localization of human resources is the most profound and most thorough localization. Many factors have contributed to the localization of talent management by multinational corporations. Localization of talents can increase local affinity, strengthen local culture and market understanding, and on the other hand use local host talents to serve local consumers to save labor costs and pipeline costs. Local people can Say local language, familiar with local traditions and behavior rules, truly understand local cultural characteristics, consumption habits, psychological needs, etc., so that they can better interact with consumers, government officials, and other stakeholders [2].

Yang Rui proposed in his article "Strategy of Localization of Talents in Multinational Companies" that the multinational companies operating in China have shown a trend of increasing the level of localization of talents in recent years, and proposed to face different national conditions and human resources conditions. A complete set of human resources management strategy was formulated, and at the same time, the merits were given in the light of actual cases, which provided lessons for all multinational companies in learning and learning.

Wang Zhaohui compares the situation of transnational corporations in the assignment of personnel and the localization of talents, and explains respectively the disadvantages of transnational corporations in the field of expatriates, especially the analysis of the aspects of dispatch, and the failure and performance of expatriates. At the same time, it is proposed that talent localization is the basis for localization of operations, and it also analyzes that talent localization is an irreplaceable role for assignments. Give us a clear impression on the advantages of local talents in multinational companies [3].

Gu Yan [4] collated and commented on the localization strategies of human resources of multinational companies in previous years. Under the background of strengthening the localization trend, he analyzed dozens of academic articles on multinational companies' human resource localization strategies, including comments on their theoretical perspectives, research methods and major research results, and based on this Summarized.

Huang Yuxin [5] talks about the necessity of localization of transnational corporations and the form of localization, including localization of talents, products, marketing, and branding, as well as backwashing the problems that localization has in the business and giving us Inspiration.

Scholars have given many inspirations and lessons to later scholars about the localization of talents. This is very important for the growth of multinational corporations in host countries, but different scholars have studied the characteristics of talent localization at all levels. There are still relatively few, but these different characteristics show that they can better use and implement the talent localization in a direction and reference for multinational companies, so that enterprises can develop healthily and avoid problems in the process of localization. So it's more important. The research in this paper is to summarize the previous research and statistics in this area and give some characteristic analysis

\section{PROPOSE HYPOTHESES}

The arrival of the era of economic globalization, coupled with the implementation of the "Belt and Road Initiative" in recent years, has enabled more and more Chinese enterprises to go abroad. In the past two decades, the global network of multinational corporations has expanded rapidly. With regard to its human resources, the localization of personnel has become increasingly apparent, and it will become an irreversible trend. However, localization is a complex phenomenon. Localization of personnel at different levels is not the same. There are many factors that affect the different characteristics of localization. Therefore, we first put forward the following assumptions.

\section{A. The Size of the Post Level Influences the Degree of Localization}

The use of expatriates in multinational companies at different levels is different. The purpose of sending expatriates to manage the host country of the host country is not only to satisfy the control of the home country, but also to open up the development path of the company to other regions because of various truth factors, thereby winning the company's distant competition. Strategic advantage. The role of expatriates is not only to guide and assist the host country's operation and production, but more importantly, to maintain the linkage and overall operation of the transnational corporations in the host country and home country. This is an important factor in the management of transnational operations. The advantages of expatriates are that they are conducive to the communication and control between the parent company and overseas subsidiaries; they are conducive to the preservation of business secrets and the protection of the company's proprietary technologies; and they safeguard the interests of the parent company and reduce business risks. The personnel sent by the home country are familiar with the conditions of the home country company and are familiar with the home country company's policies, practices, and personnel status; home country personnel are generally better able to understand the company's global strategy [6]. 
Hypothesis 1: The level of the job affects the degree of localization.

The higher the position, the more the multinational corporations tend to use their foreign counterparts, and the lower the degree of localization. Generally speaking, multinational corporations always use large numbers of foreign staff in senior management positions, use host country personnel more in intermediate management positions, and mainly use host country personnel in low level management positions, and basically do not use or Use only a small amount of expatriates.

\section{B. Different Levels of posts at the same Level will Affect the Degree of Localization}

The differences in positions at a unified level will also have an impact on the degree of localization of multinational corporations. For multinational corporations, there are many benefits to boldly using the local managerial talent in the host country. Recruitment of talents from the host country is due to the fact that local personnel are familiar with the country's commercial structure, laws, and people's habits, avoiding operational and management issues and interpersonal communication barriers caused by cultural differences, and benefiting the host government, commerce, banking and taxation. Communicate with other departments; familiar with the local business environment and reduce decision-making mistakes. As a result of the talent localization strategy, the cultural gap was eliminated to the maximum extent and the company's ability to deal with the host government was enhanced. Local talents have inherent advantages in the handling of local cultures. Plus they often have a background in Western education. This allows them to work in both lengths, communicating well with local staff and effectively working with local organizations. Negotiations can also fully comprehend the strategy of the head office and combine it with the local realities to better promote the implementation of the strategy.

Hypothesis 2: Different orientations of posts, depending on the characteristics of the position, will also affect the degree of localization.

Where human resource management jobs need to comply with local employment laws and regulations, but also to adapt to employees' different cultural backgrounds and be oriented to the local market, the localization of these jobs should be higher than others.

\section{The Degree of National Development Affects the Degree of Localization}

The localization of multinational corporations in different countries is also influenced by the degree of development of the host country. In general, what kind of international human resources management methods adopted by transnational corporations and what types of personnel are employed are closely related to the level of development of the host country. Countries with a good level of development have advantages over economically, technologically, and resource-oriented countries, as compared with countries that have developed relatively backward. Compared with the cultivation of talents, it also has great advantages.
The reason why a multinational company employs expatriates to travel to a host country for management is due to the lack of qualified host country citizens, or the fact that the mothers are sent abroad to make up for the lack of local management and technology, or to ensure effective control of the branches. Centralized. In areas where development is relatively rapid, there are more resources to train local management personnel. With the increasing number of local talents with qualified management and technical capabilities in the host country, the initial motivation for multinational companies to use expatriates will be reduced.

Assumption 3: The degree of development of the country in which the transnational corporation is located affects the degree of localization.

The branches of transnational corporations located in relatively well-developed countries and regions are more than those located in the relatively backward countries.

\section{DATA DESCRIPTION AND ANALYSIS}

On the basis of reading and researching a large amount of related literature and materials, this paper analyzes the data of previous studies and surveys conducted by scholars and integrates their research to provide practical resources and evidence for supporting the above hypotheses. The different characteristics of the localization of the company's personnel provide the inspiration and reference for transnational corporations.

\section{A. The Size of the Post Level Affects the Degree of Localization}

According to the "Foreign Enterprise Newsletter" sponsored by the Beijing Foreign Service Corporation in 1997, foreign-funded enterprises, especially large-scale multinational companies, often have a phenomenon in which low-level managers and technicians are basically local employees of the host country. Department managers, middle managers, home country personnel, and third-country personnel are all evenly distributed; high-level positions such as general managers, directors, chief representatives, etc., are basically occupied by expatriate employees of home country companies. It is relatively rare for the host country's local personnel to truly enter the core management of multinational companies and participate directly in decision-making. An example of a foreign company in China (Beijing) is used as a reference. In 1997, the status of Chinese people in foreign companies was as follows: $6 \%$ of chief representatives, representatives, or general counselors, $60 \%$ of assistants, engineers, business managers, secretaries, agents, and Others accounted for $25 \%$, and clerk, typist, driver, and waiter accounted for $9 \%$. In multinational corporations, the proportion of general managers sent by mother countries is even more. 


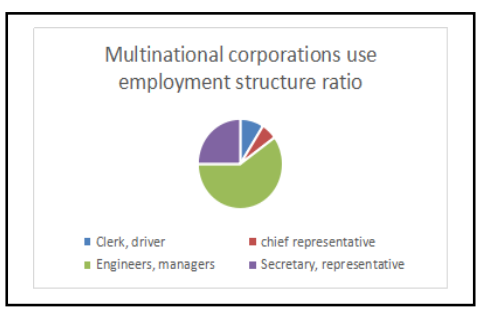

Fig. 1. Multinational corporations use employment structure ratio

The ownership of a general manager of a multinational company can be a good indicator of the degree of localization. Because the general manager is responsible for the day-to-day business operations of the company and implements the resolutions of the board of directors, some general managers also have the right to appoint other key-level managers. If the general manager comes from the host country, and the host country personnel also account for a large proportion in other management and technical positions, it shows that the localization of multinational companies has reached a relatively deep level.

Harzing conducted a small sample survey of 287 breeding facilities and found that the nationality of the general manager is significantly related to the proportion of expatriates in the top five positions. The average number of expatriates in these 287 branches is 1.33 , and the average number of expatriates in the branch offices of the host country's general managers is only 0.51 , while in the branches of expatriates serving as general managers, The average number of dispatched personnel reached 2.53, so the general manager's nationality attribution can well represent the localization level of an affiliate.

According to Mao Yunshi's data on the operating strategies of multinational corporations in China, that is, a tabular analysis of the background of the nationality of senior managers of some multinational corporations in China, The following table (Table 1):

\section{TABLE I. TABLE 1}

\begin{tabular}{|c|c|c|c|c|c|c|}
\hline \multicolumn{6}{|c|}{ The background of the nationality of senior managers of some } \\
multinational companies in China
\end{tabular}

\begin{tabular}{|c|c|c|c|c|c|c|}
\hline & \begin{tabular}{|c|} 
Shenlong \\
Automobile \\
\end{tabular} & Chinese & French & Chinese & Unknown & Chinese \\
\hline & $\begin{array}{c}\text { BMW } \\
\text { Brilliance }\end{array}$ & German & German & German & German & Chinese \\
\hline \multirow{9}{*}{$\begin{array}{c}\text { Mobile } \\
\text { phone } \\
\text { industry }\end{array}$} & $\begin{array}{l}\text { Nokia } \\
\text { China }\end{array}$ & $\mathrm{Cl}$ & Chinese & $\begin{array}{c}\text { Australia } \\
\mathrm{n}\end{array}$ & hinese & Chinese \\
\hline & $\begin{array}{c}\text { Motorola } \\
\text { China }\end{array}$ & $\begin{array}{c}\text { Chinese } \\
\text { America } \\
\mathrm{n}\end{array}$ & American & $\begin{array}{l}\text { Chinese } \\
\text { American }\end{array}$ & American & $\begin{array}{c}\text { Singapor } \\
\text { ean }\end{array}$ \\
\hline & $\begin{array}{c}\text { Samsung } \\
\text { China }\end{array}$ & Korean & Korean & Chinese & Korean & Chinese \\
\hline & $\begin{array}{l}\text { Philips } \\
\text { China }\end{array}$ & $\begin{array}{c}\text { Taiwane } \\
\text { se }\end{array}$ & $\begin{array}{l}\text { Brunei } \\
\text { people }\end{array}$ & Chinese & Dutch & $\begin{array}{c}\text { Taiwanes } \\
\mathrm{e}\end{array}$ \\
\hline & $\begin{array}{l}\text { Siemens } \\
\text { China }\end{array}$ & German & $\begin{array}{c}\text { Singapore } \\
\text { an }\end{array}$ & Chinese & Chinese & Chinese \\
\hline & $\begin{array}{c}\text { Panasonic } \\
\text { China }\end{array}$ & Japanese & Chinese & Japanese & Chinese & Chinese \\
\hline & $L G$ China & Korean & Korean & Korean & Korean & Korean \\
\hline & NEC China & Chinese & Japanese & Chinese & apanese & Chinese \\
\hline & $\begin{array}{c}\text { Alcatel } \\
\text { China }\end{array}$ & French & Chinese & Chinese & Chinese & Chinese \\
\hline \multirow{9}{*}{$\begin{array}{c}\text { Computer } \\
\text { industry }\end{array}$} & IBM China & $\begin{array}{c}\text { Chinese } \\
\text { America } \\
\mathrm{n}\end{array}$ & $\begin{array}{c}\text { Taiwanes } \\
\mathrm{e}\end{array}$ & American & Chinese & Chinese \\
\hline & HP China & \begin{tabular}{|c} 
Taiwane \\
se
\end{tabular} & $\begin{array}{c}\text { Taiwanes } \\
\mathrm{e}\end{array}$ & reign & nknown & Chine \\
\hline & $\begin{array}{c}\text { Toshiba } \\
\text { China }\end{array}$ & Japanese & Japanese & Chinese & Japanese & Unknov \\
\hline & $\begin{array}{l}\text { SONY } \\
\text { China } \\
\end{array}$ & Japanese & Japanese & Japanese & Japanese & Unknown \\
\hline & Apple Inc & Chinese & Chinese & Chinese & hinese & Chinese \\
\hline & SUN China & Chinese & Chinese & hinese & hinese & Chinese \\
\hline & $\begin{array}{l}\text { DELL } \\
\text { China }\end{array}$ & $\begin{array}{c}\text { Singapo } \\
\text { rean }\end{array}$ & inese & inese & nknown & Chinese \\
\hline & AMD China & Chinese & Chinese & hinese & Inknown & Chinese \\
\hline & $\begin{array}{l}\text { Canon } \\
\text { China }\end{array}$ & Japanese & Japanese & Chinese & Japanese & Unknown \\
\hline \multirow{4}{*}{$\begin{array}{c}\text { Daily } \\
\text { chemicals } \\
\text { industry }\end{array}$} & $G$ & lian & an & se & se & gn \\
\hline & Unilever & $\begin{array}{c}\text { Norther } \\
\mathrm{n} \text { Irish }\end{array}$ & hinese & hinese & Inknown & Unkn \\
\hline & $\begin{array}{c}\text { Amway } \\
\text { China }\end{array}$ & hinese & Chinese & hinese & hinese & Unkno \\
\hline & $\begin{array}{c}\text { Colgate- } \\
\text { Palmolive }\end{array}$ & inese & Unknown & Chinese & Unknown & Unknown \\
\hline \multirow{2}{*}{$\begin{array}{c}\text { Electrical } \\
\text { equipment } \\
\text { industry }\end{array}$} & GE China & $\begin{array}{c}\text { America } \\
\mathrm{n}\end{array}$ & Chinese & Chinese & American & Chinese \\
\hline & ABB China & Swiss & se & ese & wn & 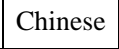 \\
\hline \multirow{8}{*}{$\begin{array}{c}\text { Top 500 } \\
\text { industrial } \\
\text { manufactu } \\
\text { ring } \\
\text { companies }\end{array}$} & BP China & British & Chinese & Chinese & Unknown & 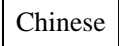 \\
\hline & \begin{tabular}{|l|} 
ExxonMobil \\
Corporation \\
\end{tabular} & $\begin{array}{c}\text { America } \\
\mathrm{n}\end{array}$ & Chinese & hinese & Unknown & Unknow \\
\hline & Shell Oil & Malaysi & Chinese & hinese & hinese & Unkno \\
\hline & Boeing & Chinese & Chinese & Chinese & Unknown & Unknow \\
\hline & DuPont & $\begin{array}{c}\text { America } \\
\mathrm{n}\end{array}$ & Chinese & Chinese & Unknown & Unknown \\
\hline & Volvo & Chinese & Chinese & Ch & hinese & Swede \\
\hline & Alstom & French & Chinese & Chinese & French & Chinese \\
\hline & Cisco China & \begin{tabular}{|c} 
Taiwane \\
se
\end{tabular} & inese & hinese & Chinese & Chinese \\
\hline
\end{tabular}




\begin{tabular}{|c|c|c|c|c|c|}
\hline $\begin{array}{c}\text { Yangzi } \\
\text { Petrochemic } \\
\text { als BASF }\end{array}$ & German & Chinese & Chinese & German & Chinese \\
\hline $\begin{array}{c}\text { The number of valid } \\
\text { data }\end{array}$ & 44 & 43 & 44 & 33 & 27 \\
\hline Chinese & 19 & 27 & 36 & 15 & 21 \\
\hline proportion & $43.20 \%$ & $62.80 \%$ & $81.80 \%$ & $45.50 \%$ & $77.80 \%$ \\
\hline
\end{tabular}

we can conclude that the configuration of multinational corporations in China for senior managers presents some differences. However, it is worth noting that the proportion of general managers and vice presidents of technology is the lowest among Chinese and Chinese, with $43.2 \%$ and $45.5 \%$ respectively, that is, decision-making power and technology core are still controlled by foreigners.

Based on the above-mentioned literature and data, we can conclude that our hypothesis 1 is established, that is, the higher the position, the more the multinational companies tend to use their foreign counterparts and the lower the degree of localization.

\section{B. Different Positions at the same Level will Affect the Degree of Localization}

According to Harzing 's investigation of the localization of 2689 multinationals, the following figure is drawn [7].

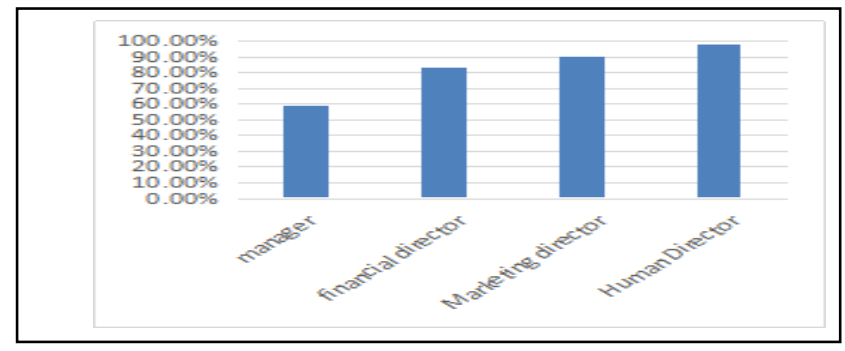

Fig. 2. The proportion of each post by the host country

The proportion of general manager positions held by the host country personnel is $59.2 \%$, and the degree of localization is the lowest. In the same level of positions, the proportion of the host country's personnel as the chief financial officer is $82.8 \%$, the proportion of the director of marketing is $89.9 \%$, and the highest proportion is the director of human resources, reaching $97.8 \%$.

At the same time, in Mao Yunshi's survey, the characteristics of localization of different posts with the same level of status are reflected in Table 1. For example, vice president of marketing and vice president of personnel have the highest proportion of Chinese and Chinese people, It is $81.8 \%$ and $77.8 \%$ respectively.

The above review confirms our hypothesis that the degree of localization of multinational companies in different positions at the same level is affected by the orientation of the positions. Because human resource management work needs to comply with local employment laws and regulations, but also to adapt to employees of different cultural backgrounds. The marketing function is also oriented to the local market. Compared to the former two functions, knowledge about local conditions and preferences is of least importance to the financial function, and the role of the chief financial officer and the general manager is equally important in terms of the control functions of the expatriates., so the localization ratio of the chief financial officer is relatively low.

Therefore, depending on the requirements and characteristics of different positions, the proportion of local talents that multinational corporations consider to appoint in their positions will also be different. In localities that are less affected by culture and regulations, the degree of localization will be relatively low. So our hypothesis 2 is true.

\section{The Degree of National Development Affects the Degree of Localization}

According to a survey conducted by Harzing A.W.K (2001) on the situation of the host country's personnel as general managers of 2,689 sample companies in host countries with different degrees of development, we can make the following summary table (Table 2):

TABLE II. TABLE 2

Localization of the General Managers of Foreign Branches of Multinational Corporations by Host Country

\begin{tabular}{|l|l|l|}
\hline \multicolumn{1}{|c|}{ Host country } & Sample company & $\begin{array}{c}\text { Percentage of host country officers } \\
\text { serving as general managers }\end{array}$ \\
\hline Scandinavia & 164 & $85.40 \%$ \\
\hline Western Europe & 1351 & $66.70 \%$ \\
\hline Eastern Europe & 81 & $60.50 \%$ \\
\hline Canada & 94 & $58.50 \%$ \\
\hline Australia/ New Zealand & 135 & $58.50 \%$ \\
\hline Latin America & 254 & $49.20 \%$ \\
\hline Africa & 53 & $41.50 \%$ \\
\hline Far East & 515 & $39.80 \%$ \\
\hline middle East & 42 & $33.30 \%$ \\
\hline total & 2689 & $59.20 \%$ \\
\hline
\end{tabular}

Source: Harzing A.W.K(2001):Who is in Charge?An Empirical Study of Executive Staffing Practices in Foreign Subsidiaries,Human Resources Management, Vol.40,No. 2,Summer.

As can be seen from the table, in the Scandinavian region (including four countries: Norway, Sweden, Denmark, and Iceland), Western Europe, Canada, and Australia and New Zealand, host country personnel serve as foreign branches of multinational corporations. The proportion of general managers was significantly higher than those in Latin America, Africa, the Far East and the Middle East. The proportion of the host country officers in Scandinavia was significantly higher than that of other regions, reaching $85.4 \%$, followed by Western Europe, which was $67.3 \%$. The proportions of localization in Africa, the Far East, and the Middle East are only 41.5\%, $39.8 \%$, and $33.3 \%$, respectively. The proportion of localization in Eastern Europe was unexpectedly high at $61.5 \%$. Tung's study also showed that the number of affiliates in Asia that employ the home country is the highest, followed by the affiliates in countries in Latin America and South America, and 
the home countries in Europe and the United States where affiliates are employed in high positions. Relatively few people.

In summary, from the perspective of the host country, the degree of localization of transnational corporations in developed countries is generally higher than that of developing countries and regions, especially those in Asia and Latin America. Analogous to the above, we can speculate that China is transnational in South and Southeast Asia. The degree of localization of talent management in the company is also similar, that is, branches of multinational corporations located in countries and regions with relatively good development level are better than branches located in relatively backward countries. So our hypothesis 3 is also confirmed to be true.

\section{DISCOVERY AND DISCUSSION}

As a result of economic integration and the "One Belt and One Road" driving force and the natural result of transnational corporations, they face different political systems, legal norms and customs, and at the same time promote mutual understanding, mutual penetration, and constant Fusion. How to adapt to a market and management environment that is very different from that of the mother country is particularly important for multinational companies. The core of current international competition is talent competition. The past overseas dispatch policies of multinational corporations have become outdated. Both management efficiency and economic efficiency have been unable to meet the global strategy implementation and overseas operation methods of multinational corporations. Talent localization has become an inevitable choice for multinational corporations to conduct human resources management and the future. The development trend is also a support point for the globalization strategy of multinational corporations [8].

Talent localization is an irreversible trend for multinational companies. The characteristics of localization on different levels are also different. How to go deeper to understand the localization characteristics of multinational corporations and use the characteristics of talent localization to better manage the company to adapt to the host country is an important issue for multinational corporations [9].

In most multinational corporations, it is easy for local people to replace the expatriate staff in the bottom manager position. The main reason is because: First, the main responsibility of the low-level manager is to execute the decision of the middle manager with a narrow scope of responsibility. The second is that local people are more familiar with markets and customers than expatriates, so they are usually more advantageous at the executive level (this is also the reason that even for the same level of positions, marketoriented positions are more localized). Finally, for companies, due to the existence of a large number of suitable local candidates and labor cost pressures due to the development of corporate organizations, replacing local expatriates with lowlevel managerial positions becomes a wise choice.

In the top managerial position, the host country's natives do not yet have sufficient competition conditions. Because the people in charge of the overall situation in the host country or regional market must be trusted by high-level multinational corporate headquarters, and this trust is usually established before the appointment. Domestic talents in the host country do not have such inherent advantages and are therefore usually not considered.

In the areas of product sales, marketing, and product localization, multinational corporations tend to use local talents. Therefore, the degree of localization in these positions is relatively high. The operation market is also basically the host country's local market, because in these areas directly related to the product, such as sales, marketing, and localization R\&D, its performance can be measured by hard indicators, and other performance of managers is negligible, even It can be "a blunt octopus," and even more important is that local people understand the basic situation of their own country better than expatriates and can better develop and execute their business.

The success of multinational companies in human resources localization strategy also depends on whether the host country can provide corresponding materials and human resources. If this condition is not met, the localization of talent will be an empty talk. Countries and regions with a comparatively good level of development have more abundant materials, human resources, infrastructure, and more qualified personnel for training. This will make it easier for local talents to be qualified for the assignment of expatriates employed in their home countries. In addition, these countries have enough Market space and development potential. If the space is large enough, it will promote the implementation of localization. On the contrary, it will limit the implementation effect of multinational corporations' localization.

The degree of localization of managers is a key factor in determining the success of localization. Only by fully understanding the characteristics of localization can multinational corporations be able to appoint talents rationally from the perspective of human resource characteristics, improve the company's localization framework for human resources, and better develop multinational corporations [11].

\section{CONCLUSION}

As the trend of economic globalization becomes more and more obvious today, the "One Belt and One Road" is also being promoted. Multinational corporations are the main carriers of economic globalization and the "Belt and Road Initiative". Their competitiveness is not only reflected in their strong capital, advanced technologies, Well-known brands, a sound sales network, and scientific management, and more importantly advanced talent management models. Because with the intensification of competition in the international market and the globalization of multinational corporations, it is difficult to rely on the talents of home countries to meet their growing needs. Therefore, multinational corporations must put their talent allocation within a broader scope. Only in this way can we recruit enough people to fit the company's development. In many human resource management models, the localization of human resource management has become a common model adopted by multinational corporations. The localization of talent management has become the cornerstone for the development and growth of the company. 
Talent localization can optimize the allocation of human resources, so that talents can have more room for development, so that the value of local personnel can be realized. In addition, the demand for the localization of multinationals personnel has also promoted the improvement of the talent market and promoted the formation and development of the talent circulation system and talented person network management system [10].

In the context of the "Belt and Road Initiative," China will work hard to promote economic integration with South Asia and Southeast Asia, and take the path of mutually beneficial development and win-win progress. In terms of strategy, multinational companies can't limit their attention to the domestic market, but must look globally. While recognizing the importance of talent localization, multinational corporations must also recognize the degree of localization at each level, so as to enable them to grasp the golden opportunities for development.

This article is mainly carried out through the analysis of the universal phenomenon of multinational companies' localization and the three characteristics that affect the localization of talents. The purpose of this article is to explain the factors affecting localization so that multinational corporations can design a reasonable human resource structure and employ scientific management talents. Accelerate company operations and development.

\section{LIMITATION}

There are still limitations to this study. First, the data report is not the latest data, and the survey form itself is a weak link in the investigation and research. The data sample is not large enough. Furthermore, comparing the degree of localization between developed and developing countries, analogous to countries with a good degree of development in South Asia, Southeast Asia, and relatively backward countries, multinational companies in China are analogous to all multinational companies, which is not accurate. Then, this paper only demonstrates three factors that affect the localization characteristics, without considering other factors, so the information is not comprehensive.

With regard to the field of transnational corporations' outsourcing and localization and localization characteristics, there should be more issues that should be studied and in-depth. Therefore, in the future research, we should also invest more energy in in-depth interpretation of multinational corporations localization issues, such as other issues that need to be explored, such as the efficiency of localization to multinational corporations.

\section{ACKNOWLEDGEMENT}

I am a first-year graduate student and there are not enough documents and periodicals to read. So there are still many deficiencies in writing this paper. Some places are not professional enough, but I put my best energy into this. At the international conference, I hope I can better perfect myself and improve the study of this paper.

Finally, I would like to express my sincere thanks to all editors and reviewers. Of course, my tutors and classmates gave me guidance and help in completing this essay. I will live up to everyone's expectations and produce more satisfying works in the future. Thank you very much.

\section{REFERENCES}

[1] Habo Wen.The Localization Strategy of Multinational Corporations and Its Enlightenment[J].Shopping Mall Modernization,2014(28):70-71.

[2] Lu Yuanquan,Wang Fang.The implementation of the localization strategy of talent utilization in multinational corporations[J].Journal of Anqing Teachers College(Social Science Edition),2008,27(11):116$117+121$.

[3] Wang Zhaohui.Comparative Study on Transnational Corps Staff Assignment and Talent Localization[J].International Economic Cooperation,2006(06):55-57.

[4] Gu Yan.A review of multinational corporations human resources localization strategy $[\mathrm{J}]$.Commercial Culture(the second half),2011(03):39-40.

[5] Huang Jingxin.Analysis on the Localization Strategy of Multinationa Corporations and Its Implementation[J].Chinal's Economic and Trade Journal,2015(26):57-58

[6] Wang Fang.Discussion on Talent Localization Strategy of Multinational Corporations[J].Journal of Sichuan Administration College, 1999(03):5051.

[7] Ge Zheyu. The Status Quo of the Localized Management of Senio Talents in Multinational Corporations: A Case Study of Multinational Companies in Europe, the U.S., Japan, and Korea[J]. Modern Business, 2015(23):157-159.

[8] Sun Zhe. Research on Human Resources Localization of Multinational Corporations in China[D]. Qingdao University, 2009.

[9] Cai Liang. Empirical research on the localization of human resources in multinational corporations in China[D]. Anhui University of Finance and Economics, 2014

[10] Zhang Wenguang.Human Resource Effects of R\&D Talent Localization Strategy of Multinational Companies in China[J].Shandong Social Sciences, 2011(08):128-131.

[11] Wu Xiaohong. A Study on the Gradient Localization Strategy of Managing Talents of Multinational Companies in China[D]. Hunan Normal University, 2008. 